Article

\title{
Poor, Wayfaring Stranger: Erik Peterson's Apocalyptic and Public Witness against Christian Embourgoisement ${ }^{1}$
}

\author{
Patrick Ryan Cooper \\ Saint Meinrad Seminary \& School of Theology, 200 Hill Drive, St Meinrad, IN 47577, USA; \\ pcooper@saintmeinrad.edu \\ Academic Editor: Justin Sands \\ Received: 3 February 2017; Accepted: 20 March 2017; Published: 23 March 2017
}

\begin{abstract}
With the present collection of essays reflecting upon the complex convergences and divergences between Eschatology and genuine transcendence, there is perhaps no greater modern Catholic figure to recall than that of the great, German Catholic convert Erik Peterson (1890-1960). As an immediate forerunner to twentieth century Catholic ressourcement, eschatology, for Peterson, not only factors as the central arc within his diverse corpus of writings, yet he himself is equally credited for having coined the phrase, 'the eschatological proviso' in describing the coming of the Kingdom as both 'already' and 'not yet'. Fundamentally, Peterson's proviso presents a historical view of the suffering Church as necessarily beyond political confinement and ideological capture. As a pilgrim community in-between the "earthly Jerusalem, which is at once polis and temple" and its "ever drawing closer to the eschatological, heavenly temple and its own ... polis", Peterson bears witness to this ontic difference in his writings by framing the Church's distinctly public act, the liturgy, as the site of a transversal commericum. That is, an angelic participation within the earthly cult as well as her "participation in the worship that the angels offer to God." In this following contribution, I will examine this eschatological provision as the primary governing optic by first contextualizing Peterson's critical reception of historicism and its methodological atheism (Troeltsch, Harnack) within German liberal Protestantism and the Religionsgeschictliche schule as the necessary precursor to his conversion. Secondly, I will build upon these critiques in view of Peterson's concise and influential 1950 essay, "Kierkegaard und der Protestanismus" that theologically focuses specifically upon his attack against Barthian dialectic and its inability in approaching the very concretissimum of revelation and its ecclesial extension of dogma as none other than the "concrete continuation of Christ's assumption of a body". Lastly, in view of genuine transcendence, the ambivalent influence of Kierkegaard will be more positively assessed in terms of Peterson's long held attack upon the bourgeois character of much of modern Christianity. As an immediate parallel to the critique of secular, historical immanentism, focus will center upon the martyrological witness of the poor as aptly encapsulating Peterson's theopolitical vision. Herein, the invisible poor function as an "eschatological symbol" that lays at the porous threshold of genuine transcendence (Lk. 16, 19-31) wherein Christ recognizes the depths of his very divine person and in whom the poor are integrally inseparable through their witness.
\end{abstract}

Keywords: Erik Peterson; apocalyptic; eschatology; martyrology; Kierkegaard; theo-politics; poverty

\section{Peterson's Apocalyptic: Future and Present}

With the present collection of essays reflecting upon the complex convergences and divergences between eschatology and transcendence, there is perhaps no greater modern Catholic figure to recall

1 In the following essay, all translations of Peterson's works are mine, unless stated otherwise. 
from unwarranted obscurity than that of the great, German Catholic convert, Erik Peterson (1890-1960). As an immediate precursor to twentieth century Catholic Ressourcement, the complexity of Peterson's writings and interests are exceptionally diverse, yet never become overly specialized and disparate and instead evince an abiding attention to the "whole of theology". ${ }^{2}$ This would include his primary formation as a notable Church historian formed in Göttingen ([1], p. 20) ${ }^{3}$, focusing especially on early and Near-East Christian antiquity [2]. Peterson, however, would ultimately grow to be at odds with its famous Religionsgeschichtliche Schule and the neutrality of its "methodological agnosticism" in its comparative research of historical religions, which in the end would prove formative. Equally formative, the mystical bent of Peterson's German Pietism from his student years would carry over, and more specifically, his untiring, albeit critical fondness for Kierkegaard (which we shall explore later on) as ultimately laying the groundwork in immediately predating his conversion.

Today, within English language scholarship-which has greatly benefitted from the scholarship and translations offered by Michael Hollerich-Peterson is perhaps best known for his political theology and divergences with Carl Schmitt, as seen in Monotheism as a Political Problem (1935) ([3], pp. 68-105). Nevertheless, his dogmatic, fundamental and liturgio-mystical theological writings all deserve equal attention, as found in compilations such as Theological Tractates (1951/ET 2011) [3] and Marginalien zur Theologie (1956) [4]. These collections exhibit a wide-ranging fluency in subject matters that include: his defense of Kierkegaard and attack upon Barthian dialectic in the early polemical "What is Theology" (1925) ([3], pp. 1-14); exploring the secularizing of the main Protestant principles in Heidegger from which Kierkegaard's pietism ultimately occludes in later essays such as "Kierkegaard und der Protestantismus" (1947) ([4], pp. 56-62) and "Existentialismus und Protestantische Theologie" (1947) ([4], pp. 52-55); his published Correspondences with Adolf von Harnack (1932) ([3], pp. 15-29) that eloquently demonstrate the "Catholic principle" of the hermeneutics of Tradition; his unique approach to the grace/nature question in "Theology of Dress"(1934/1946) ([4], pp. 10-20; [5], pp. 558-68); to that of his liturgical and theo-political mysticism evinced in his exquisite angelology, "The Book on the Angels"(1935) ([3], pp. 106-42). Of this latter text, it must be said, that perhaps alongside the sophianic metaxology of Bulgakov's Jacob Ladder [6], that together, these two texts constitute the most innovative and constructive retrievals of this largely eclipsed discourse within the past century.

Despite, however, such wide diversity of scholarship, it is undoubtedly Peterson's apocalyptic eschatology — perhaps best attested to in his prophetic "Witness to the Truth" (1937) ([3], pp. 151-82)—which evidences apocalyptic as none other than the central arc within his diverse corpus of writings. ${ }^{4}$ The convergence of eschatology and transcendence is herein consistently framed in Peterson's Apocalyptik as a particular form of eschatology, which overall entails both immanent and transcendent dimensions, as well as public and personal resonance in its unflinching, yet hopeful anticipation towards the climatic end of history and the second coming of the Christ. ${ }^{5}$ Apocalyptic eschatology, let us be clear,

2 Cf. Pope Benedict XVI, "Address of His Holiness Benedict XVI to Participants in the International Symposium on Erik Peterson" (25 October 2010): "I discovered the figure of Erik Peterson for the first time in 1951 ... I read the book [Theological Traktates] with increasing curiosity and let myself be truly impassioned by it because in it I found the theology I was seeking: it is a theology that uses all the seriousness of history to understand and study texts, it analyzes them with the full gravity of historical research and does not relegate them to the past." Benedict later goes on, "Thus I learned from him, in a most essential and profound way, what theology really is. And I even felt admiration, because here he does not only say what he thinks, but this book is an expression or a quest that was the passion of his life."

3 Also, to be noted is Peterson's associations with Gōttingen's movement of Realist phenomenology and its response to Husserl's famous, “Zu den Sachen selbst!" Cf. ([1], p. 20)

4 Peterson's official biographer and historian of ideas, Barbara Nichtweiß, convened an international symposium on this precise question in 2001 that resulted in the publication, [1]. Vom Ende der Zeit: Geschichtstheologie und Eschatologie bei Erik Peterson. See also [7].

5 In this regard, a conversant contrast to Peterson's apocalyptic can be found in Rene Girard's "On War and Apocalypse", [8]. Herein, Girard's approach is distinguished from Peterson by a greater immanentization of apocalyptic urgency as he contends that "Christianity is the only religion that has foreseen its own failure. This prescience is known as the apocalypse." With provocative insight and finesse, Girard substantiates his appeal for greater imminent urgency in his reading of the famous Prussian military analyst, Carl von Clausewitz and his treatise On War, as possessing greater range than mere 
does not entail a fanciful flight from history. Rather, it seriously and integrally approaches the Church's faith and revelation's concrete and intrinsically historical character by approaching transcendent ultimacy through analogical and symbolic discourse. Generally, apocalyptic eschatology engages with the eternal and history's dramatic terminus in part to meaningfully discern the spirit of the times and one's own situatedness within such historical unfolding. ${ }^{6}$ More specifically, Peterson's own apocalyptic combines clear prophetic strands, along with a clear sense of ease and facility of thought that at times penetrates the visionary and symbolic in a manner that is altogether " "public"" and distinctly non-idiosyncratic, in keeping with the best of the Patristic tradition. These definitive features are in turn accentuated by the very decisiveness of the martyr, who witnesses to the whole of theology itself, as the "concrete actualization of the fact that the Logos of God has spoken concretely of God, so that there is thus concrete revelation, concrete faith, concrete obedience." ([3], p. 11)

Commenting upon the important, yet nuanced differences between eschatology and apocalyptic, Bernard McGinn — one of the pre-eminent scholars of the history of Christian mysticism —was and remains to this day an equally notable historian of (late) medieval apocalyptic thought (which must be said, bares significant overlap with the mystical theological tradition in many respects). In his early anthology, Visions of the End: Apocalyptic Traditions in the Middle Ages, McGinn helps clarify this nuanced, yet integral distinction between eschatology and apocalyptic and the issues surrounding immanence and transcendence, present and future apocalyptic that are at the heart of these literary and theological discourses:
A more serious confusion has been caused by the fact that historians of Christian thought have sometimes used eschatology and apocalyptism as interchangeable terms. This is misleading. Every Christian view of history is in some sense eschatological insofar as it sees history as a teleological process and believes that Scripture reveals truths about its End. But it is possible to be orthodox and deeply eschatological and yet distinctly anti-apocalyptic, as the case of Augustine shows. It is true that the apocalyptic author frequently differs from the merely eschatological one more in degree than in kind, and it is not always easy to say when a particular writer or text is one or the other. But there is still an important difference between a general consciousness of living in the last age of history and a conviction that the last age itself is about to end, between a belief in the reality of the Antichrist and the certainty of his proximity ... between viewing the events of one's own time in the light of the End of history and seeing them as the last events themselves." ([10], p. 4)

With these important distinctions in mind, Peterson's apocalyptic eschatology, despite its clear prophetic tendencies, nevertheless retains a certain unshakable reserve, grounded ultimately in the liturgy that foregoes sole focus on 'present apocalyptic', as seen for example in the following passage from The Book on the Angels: "amid all the suffering of this worldly age, amid all the turmoil and demonic struggles with this Aeon, there remains eternally and unshakably that worship that the angels render to the Eternal One, in which earthly worship takes part." ([3], p. 110). Peterson elaborates upon this prioritization in commenting upon the Book of Revelation's peculiarity in frequently presenting eschatological visions, only then to be "interrupted by liturgical-hymnic 'insertions". By this observation, Peterson proceeds to argue that these hymns do not evidence a disparity between the original, eschatological text and its latter redaction. Instead, these hymns demonstrate a greater "urgency": namely, the public contrast of the liturgy with that of the eschatological events and the terror of their unfolding:

strategy; instead, Girard argues that Clausewitz's mimetic account is rooted in a "stunning intuition" about modernity's "acceleration of history" as none other than a reciprocal "trend to extremes", as witnessed today by a "new stage in the escalation to extremes" amid the ever-increasing brutality of modern warfare and terrorism.

6 See ([9], p. xiii): “The history of Christian Apocalyptic reveals one thing very clearly: the desire of the human soul to find a significant place for itself in the time process." 
More urgent than any communications on the eschatological events is the report on the vision of the heavenly throne room and of the heavenly divine liturgy .... .A portrayal of the eschatological events in the cosmos therefore has to make manifest the backdrop of an 'eternal' world, and the portrayal of the terrible suffering of the eschatological time likewise has as its necessary backdrop the description of a world that has been snatched away from suffering and only knows the praise of God ([3], p. 110).

For Peterson, the consistency of such liturgical interruptions renders his prioritization upon such a transcendent backdrop as neither aloof nor blithely indifferent to the political. Rather, it liturgically attests both to the rupture and always greater sovereignty of God's glory as much as it constitutes the Church's most public and therefore perfect resistance to otherwise being captured and defined by such eschatological sufferings.

However, emphasis laid upon these two distinct tendencies do not amount to two dialectically conflicting poles. In this respect, it is important to recall that Peterson himself is equally credited for having coined the phrase, 'the eschatological proviso', which was later on popularized by the New Testament scholar Ernst Käsemann. By describing the coming of the Basileia of God-as both 'already' and 'not yet' - Käsemann is equally well-known for having declared apocalyptic as the "mother of all Christian theology" ([11], p. 121). ${ }^{7}$ In a similar vein, Peterson's lack of a certain schizophrenic polarity is again attested to by Käsemann, as he frames the very historicity of apocalyptic as utterly central in producing not only a historical consciousness within early Christianity itself, yet equally and thoroughly contests the historical consciousness of secular modernity and its attempts at unreservedly moving beyond apocalyptic and its "mythical character" as none other than unwittingly ensconced in "preserv[ing] history's eschatological character" ([11], p. 96). Theologically, Käsemann equally contends that the dialectic between every age's renewed enthusiasm for "present" apocalyptic, its socio-political object and the mitigated, Augustinian reserve of "future" apocalyptic none other than soteriologically "mirrors the cosmic contention for the lordship of the world" as "man's life can only be understood apocalyptically". That is, between the sacramental economy of redemption and "ultimate salvation which lies yet ahead [and] is nothing else but the projection into the human condition of the Christian of the relationship of the lordship of Christ to the subjection of all cosmic principalities." ([11], p. 136). Hence, any and all secularization and/or immanentization of the 'present' apocalyptic alone, both of which maneuvers to elide 'future' apocalyptic of its transcendental character are both historically and theologically questionable at best.

That said, in the position taken in this following essay, under Peterson's lead, what matters most is how we conceive of this co-implication between present and future apocalyptic and the radical character of its ultimate, eschatological significance.

\section{Eschatological Decisiveness}

The appeal and indeed, urgency of apocalyptic literature-from traditional, canonical sources such as Daniel and the Book of Revelation-in addition to the innovative texts on the "Son of Perdition" as found in the Tiburtine Sibyl; the eschatological promise of the Last Christian Emperor in Pseudo-Methodius; Joachim of Fiore's exceptionally influential view of the ages of history; the Franciscan Spirituals adherence to Francis' primitive rule on holy poverty and its apocalyptic fervor ([10], pp. 43-49, 70-76, 126-42, 203-25); to the failed millenarianism of Müntzer and the peasant revolt in Germany [13,14]; the sophianicity of Solovyov's A Short Tale About the Antichrist [15]; to the more popularized, apocalyptic Mariologies of Fatima and La Sallette, as well as the "day of Mercy" before the "Day of Justice" in the diaries of St. Faustina Kowalska [16] ${ }^{8}$-all attest that interest

7 See also ([12], p. 151).

8 C.f. ([16], n. 1588): “Today I heard the words: In the Old Covenant I sent prophets wielding thunderbolts to My people. Today I am sending you with My mercy to the people of the whole world. I do not want to punish aching mankind, but I desire to heal it, pressing it 
in apocalyptic eschatology is always renewed in times of historical upheaval, unrest, crisis and in particular, religious violence.

It is thus entirely appropriate to reengage in such scholarly reflections, both in terms of the many submerged, secularized apocalyptic narratives that pervade the current cultural imagination: from the pending demise of the Western order of neo-liberalism and the resurgent face of neo-Fascist nationalism in a decidedly "post-truth" milieu; to that of the well-entrenched environmental apocalyptic and its forecasted cataclysm; to that of the more decidedly religious apocalyptic [17]. Concerning religious fundamentalist violence, terrorism and the political propagation of "persecution" and religious freedom, apocalyptic narratives have always been invested with the figure of martyrdom, and par excellence, the martyrdom of Christ, who sought not his " own will but the will of him who sent me. If I bear witness to myself, my testimony is not true" (Jn 5, 30-31). Such witness continues well into this day, this new century of martyrs of the margins [18], who embody the vulnerable extension and brutal suffering of his body, the Church. The countless witness of such martyrs regularly expose that the Church today however persists without a compelling theological approach to the odium fidei that is at once inseparable from the concretissimum of life and the public witness of their gruesome glory that resists political counterfeit. For the martyrs' silent witness is nonetheless often perversely swallowed up and co-mingled with the ideologically possessed, political counter-witness of those distinguished by their violent self-determinacy and endless self-promotion of glory to the extent that these vast differences appear largely indistinguishable today. Thus, it is in this respect that Peterson's writings, especially "Witness to the Truth", constitutes a major contribution to this otherwise "marginal" theological discourse. ${ }^{9}$

For Peterson, the charism of the martyr is an absolutely necessary dimension for any and every genuine ecclesiology, as he remarks: "Is it not necessary that the Son of Man suffers these things?'“(Lk. 24, 26), which he later on clarifies is not solely of an exclusive Christological reference, but is itself expansive, such that it "applies to the whole Church" ([3], p. 156). The truth of the martyrs' charism, in other words, is the truth of the Church in her foundations and in her holiness as a countless multitude. For such a multitude becomes 'contemporaneous with Christ', as Peterson's ecclesiology of the mystical body views this "eschatological fellowship" of suffering not merely in moral terms; that is, as a suffering 'for' Christ. Rather, Peterson sees it as far more ontological and trans-historical; that is, as a suffering "with", both individually and collectively and thus, "demonstrates the public claim" of the Church ${ }^{10}$. In this regard, it is constructive to contrast the radically apocalyptic and ontological thrust of Peterson's view of martyrdom with that of Aquinas' moral qualification of martyrdom as one of 'intentionality' in dying for a human good: "Human good can become divine good if it is referred to God; therefore any human good can be a cause of martyrdom, in so far as it is referred to God."11

Despite similarities with Aquinas' more "expansive" designation of who constitutes a martyr, the radical character of Peterson's apocalyptic eschatology breaks any presumption of an immanent natural order that is somehow bracketed apart from such ultimacy. As we shall see later on in our discussion concerning the blessed poor, Peterson's stress results in neither a confined nor restrictive designation of martyrdom itself; rather, emphasis is made upon the necessarily "public" character of the martyr, over and above any private intentionality, in witnessing such an eschatological porosity,

to My Merciful Heart. I use punishment when they themselves force Me to do so; My hand is reluctant to take hold of the sword of justice. Before the Day of Justice I am sending the Day of Mercy."

9 See generally, ([19], p. vii): "In order to see and understand the contemporary Church as a Church of the martyrs, one must observe that there is something like a historical and cultural shift in the pattern of martyrdom and the image of the martyr. There is something like a shift from the 'heroic' to the 'anonymous' martyr, from individual martyrdom to a kind of collective martyrdom."

10 See generally the prison writings of the 20th Century Austrian martyr, Franz Jägerstätter ([20], p. 180), who at one point writes: "By his harsh suffering and earthly death, Christ has redeemed us from eternal death but not from earthly suffering and death. Christ demands from us also a public acknowledgment [confession] of our faith, exactly as the Führer Adolf Hitler demands from his Volk."

11 See 2a. 2ae. Q. 124 ad 3, as quoted from [21]. 
a tearing open, as much as it demonstrates a compelling historical resistance to the reigning powers and principalities. By this, the martyr makes visible the Church's pilgrimatic nature as necessarily between the heavenly and the earthly. From this between, the martyr, Peterson writes, "leaps beyond this world's concept of 'public' and demonstrates ... the public claim of another, a coming world", yet does so always concretely and immanently from within ([3], p. 157). Herein, the theo-politics of Peterson's eschatological "public", both in its porous breaking in, and resistance signals none other than the eschatological ultimacy that "dissolves" any pretense of autonomy of the natural order, such as the bonds of family, race, class and state; the compromise of their counter-weight are torn by the critical time of the messianic age that requires decision ([3], p. 152).

The decisiveness of the eschatological rules out neutrality as much as it discerns the political as either a source of God's glory or as an idolatrous, cultic object of its own worship. Peterson contrasts these dueling publics, between Jerusalem and Babylon, wherein he states:

Babylon, the great whore, has fallen, the merchants, traders and shipmasters raise a song of great lament (Rev 18,11-19). The brilliance of the political is exposed after the fall of Babel as in reality the economic profit of international commerce .... Where Jerusalem is, there is simplicity, yes, even possibly poverty, yet the splendor of the virgin is in heaven, with God and the Lamb; she therefore has no need of a splendor borrowed from the earth, which in the final analysis can only serve to enrich international business ([3], p. 168).

These dueling contrasts of the political and Peterson's radical theo-politics foster a uniquely robust, liturgical critique of capitalism itself and concentrated in the intrinsically public dimensions of the martyr. For in the martyrs' suffering flesh, the glory of Christ becomes brutally concrete; it becomes "revealed" and thus possesses immediate "public" significance in unveiling the enduring metaphysical conflict between Babylon and Jerusalem. In the martyr, and precisely due to the porosity of its in-breaking, the glory of Christ thus becomes radically political in its counter-sovereignty $(\mathrm{Jn} 18,36)$ to the reigning powers and principalities ([22], pp. 67-114).

For Peterson, as we shall see shortly in exploring his relation to Kierkegaard, it is the testimony of the martyrs as a "Witness to the Truth" that exemplifies the fullness of both human and Christian existence itself in their "contemporaneity with Christ" precisely in their determinate lack of self-determinacy.

We become man to the extent that in our existence we draw near to the Son of Man. But the highest form of appropriation to the Son of Man in discipleship is that of the martyr ... . what Kierkegaard called 'contemporaneity with Christ.' Of the martyr (the saint) can we thus say that he is most truly man ([23], p. 171).

The weak strength of this kenotic witness none other than confirms the mystery of man and that of the Church as ecclesia martyrum-beyond reductive confinement and institutional, bourgeois capitulation-as it unveils the "eschatological mystery" itself. For the necessary public dimensions of the martyr's death iconically "manifests God" and "always opens the heavens"—as it was with the proto-martyr Stephen and his stoning, who in the eloquence of his frailty, O Heiland, reiß die Himmel auf, reveals an open porosity, a transversal commercium ${ }^{12}$ that imbues the political with the eschatological. For such a commercium resists "degenerating" into Heideggerian finitude and confusing such witness with the "fleeting commitment of a historical or political responsibility" ([4], p. 55).

This martyrological figure of deliberate renunciation and absolute dependence, in its idiosyncratic manner, resists facile glorification, yet is perhaps best conveyed by the ancient eschatological symbol

12 See the liturgical, Eucharistic and deification themes in: The Martyrdom of Polycarp, ([24], n. 15.1-15.2): “And when had offered up the 'Amen' and finished his prayer, the men [attending] the pyre lit the fire .... .For the fire made the form of a vault, as a ship's sail filled by the wind, walling around the body of the martyr. And it was in the middle not as flesh burning, but as bread baking, or as gold and silver refined in a furnace. For we also experienced such strong fragrance, like a waft of incense or some other of the precious spices." 
of the Church as a "Ship" which Peterson writes upon in Frükirche, Judentum und Gnosis. ${ }^{13}$ The ship here, of course, is what was later on understood as the barque of Peter, though not to be confused with the later ships of imperial glory and colonial conquest, but far more akin to the miserably overcrowded vessels that today, migrants and refugees aboard to their frequent, terrible peril in crossing the Mediterranean. ${ }^{14}$ In characteristic fashion, Peterson draws upon the Jewish typological and early Syrianic roots of the image of the Church as a ship, as seen, for example in the 3rd Century baptistery of the well-known Dura-Europos house church in present day Syria. Peterson theologically expounds upon these diverse historical origins by linking it to a telling aside made by Tertullian in his De baptismo (n. 12) wherein the Church Father immediately abandons discussion of whether or not all of the apostles were baptized and instead inserts, as though it were of an older tradition and/or source, a description of the Church with a "decidedly eschatological coloring", describing the Church as a:

little ship ... tossed about by the waves, which means persecutions and temptations, while our Lord in his long-suffering is as it were asleep, until at the last times he is awakened by the prayers of the Saints to calm the world and restore tranquility to his own ([2], p. 92).

From this interesting aside that so suddenly emerges within Tertullian's text-hence prompting speculation as having derived from an earlier source-Peterson once again immediately expands upon this eschatological symbolism of the sea storm and the figure of the Church as a "little ship", thrust upon its waves. However doing so this time, Peterson makes what is seemingly a far more innovative linkage: namely, as formulating an immediate counter response to another reoccurrence of this symbolic figure, this time found in Clement of Alexandria's short work, Quis dives salvetur [Who among the rich might be saved]. For unlike the rich man who vainly sought out perfection (Mk 10, 17-31), of whom Clement himself immediately allegorizes ${ }^{15}$, while refusing the more "humanly literal" interpretation, ${ }^{16}$ we can constructively extrapolate Peterson's subtle contrast as itself emphasizing the very decisiveness that the eschatological ushers in, at once countering the solely 'spiritualizing' biblical hermeneutic well-established within the Alexandrian tradition, all of which is insufficiently "ruled out" by the eschatological ([3], p. 154). While by contrast, seeking a certain neutrality and/or compromise, thus in turn risks the little ship becoming "submerged" under the waves, "only to once again become afloat" as it is "guided solely by the "prayers of the saints'"([24], n. 34). The connection that Peterson draws out is not merely to illustrate the theme of dependence, of the ship mercilessly being tossed about the waves, aided only by saintly intercession. Rather, the curiosity of these linkages is none other than the profound connection that Peterson is here alluding to, namely the eschatological significance of the poor and their own uniquely privileged, martyrological witness in whom Christ recognizes himself. At the conclusion of these reflections, we will return to the eschatological significance of the poor as a unique, martyrological symbol in Peterson's work. But first, more needs to be said about one of the

13 Cf. Erik Peterson, "Das Schiff als Symbol der Kirche in der Eschatologie” in ([2], pp. 92-96).

14 See for example, Francis. "Address to the Jesuits on the occasion of its Bicentennial Reestablishment September 27, 2014." Available online: http://w2.vatican.va/content/francesco/en/speeches/2014/september/documents/papa-francesco_ 20140927_vespri-bicentenario-ricostituzione-gesuiti.html (accessed on 12 December 2016): "Let us remember our history: "the Society was given the grace not only to believe in the Lord, but also to suffer for His sake" (Philippians 1:29). We do well to remember this. The ship of the Society has been tossed around by the waves and there is nothing surprising in this. Even the boat of Peter can be tossed about today. The night and the powers of darkness are always near. It is tiring to row. The Jesuits must be brave and expert rowers (Pius VII, Sollecitudo omnium ecclesiarum): row then! Row, be strong, even against a headwind! We row in the service of the Church. We row together! But while we row-we all row, even the Pope rows in the boat of Peter-we must pray a lot, "Lord, save us! Lord save your people." The Lord, even if we are men of little faith, will save us. Let us hope in the Lord! Let us hope always in the Lord!" [25].

15 C.f. ([24], n. 5): "And as we are clearly aware that the Savior teaches His people nothing in a merely human way, but everything by a divine and mystical wisdom, we must not understand His words literally."

16 C.f. ([24], n. 11): "'Sell what belongs to thee.' And what is this? It is not what some hastily take it to be, a command to fling away the substance that belongs to him and to part with his riches, but to banish from the soul its opinions about riches, its attachment to them, its excessive desire, its morbid excitement over them, its anxious cares, the thorns of our earthly existence which choke the seed of the true life." 
principal sources that frame Peterson's approach to the eschatological itself as initiating this time of ‘decisiveness'.

\section{Against Bourgeois Capture}

To understand the figure of the martyr in his decisive eschatological significance, for Peterson, one must contend with the centrality of Kierkegaard who, along with the mystical leanings of Peterson's student days and his involvement in the German Pietist movement (Deutsche christliche Vereinigung) [1] these two influences formed a bridge over the Tiber both in terms of its continuity and rupture amid Peterson's own conversion. Peterson himself confirms such an influence, as seen in the notes of his Epilogue to his published correspondences with Adolf von Harnack: "Seen psychologically, Pietism and Kierkegaard have perhaps given the decisive impulse to [my] return to the Catholic faith." ([3], p. 193, footnote 10)

Such a "bridge" frames Peterson's view of the eschatological beyond as rightfully intensifying the dramatic within of historical existence, which he evaluates concerning the vocation of holiness, the communion of saints and the witness of the martyr set against man's demonic sickness and the institutional Church's otherwise bourgeois capture. ${ }^{17}$ "If there is anything opposite of the spirit of bourgeois comfort," Peterson reminds us, "it is primitive Christianity, which in the mouth of the martyr in Revelation blasts us like some fiery breath." ([3], p. 171).

It is especially this martyrological witness of life and faith, this "Zeugnis der Wahrheit", that recalls both Peterson's own highly inspired apocalyptic eschatological writings, as well as Kierkegaard's own rebuttal of the increasingly bourgeois character of the Danish Lutheran Church. ${ }^{18}$ As seen in his Attack upon Christendom, Kierkegaard publically engaged in a serial of relentless attacks upon Martensen, the Danish professor, who in 1854, publically eulogized the recently deceased Bishop Mynster of Seeland as a "witness of the truth" - a public occasion that became a lightning rod of antagonism and which represented for Kierkegaard the inescapable paradox of orthodox Lutheranism's own Hegelian compromise [27].

In Kierkegaard's analysis, the sola fide of the Danish Church had become abstractly "idealized" and overly gnostic in its duality and thus increasingly and paradoxically divided from the concretissimum of life and intentional religious forms of life and the decisiveness of vocation and the call of holiness. Instead, Kierkegaard strongly inveighs against what Peterson later calls this "Vermittlungstheologie" - this theology of mediation and compromise with the world; in other words, an accommodationist, contextual theological approach that both Bishop Mynster and Martensen had embodied. More specifically, the "compromise" between Hegel and orthodox Lutheranism resulted, on could say, in an overly juridical, nominalistic view of interior grace that firmly excludes such witness in the first place as anything other than bland, pious rhetoric that aims to reconcile 'spiritual martyrdom' with institutional, bourgeois capture. Hence, Kierkegaard's protest simultaneously becomes Peterson's, in their mutual refusal to abandon the concretissimum of the martyr.

For Kierkegaard, the charism of the martyr as a 'witness to the truth' is both entirely decisive and utterly opposed to what he-having grown up with a father withsimilarly strong Pietist leanings-regards as the nearly inescapable theological impasse and consequential embourgoisement of the Danish People's Church. ${ }^{19}$ For Kierkegaard, this decisiveness is entirely evident, as he describes the martyrological witness as one of

17 See ([12], p. 156): “[Peterson] had read Kierkegaard intensively at an earlier stage of his career. Despite his reservations about Kierkegaard's exaggerated subjectivism, the Danish philosopher remained for him a prototype of Christian alienation from the embourgoisement of modern Christianity."

18 See generally ([26], pp. 86-91) for Joshua Furnal's summary analysis of Peterson's formidable, theological reading of Kierkegaard and its considerable influence in the post-war years leading up to the Council.

19 For a general discussion of the influence of Pietism on Kierkegaard, See generally, [28]. 
[P]overty, lowliness, in abasement ... for him there was never promotion, except in an inverse sense ... the last promotion, as defined by the Christian protocol ... at last crucified, or beheaded, or burnt, or roasted on a gridiron ... his lifeless body thrown by the executioner in an out-of-the-way place ... or burnt to ashes and cast to the four winds, so that every trace of the 'filth' might be obliterated ([27], p. 7).

We would be entirely mistaken to see in Kierkegaard's impassioned rhetoric some perverse, heroic romanticization. Rather, in the man who "wanted to make Christianity difficult for his idealist contemporaries" ([4], p. 56), his words are completely and utterly foreign to his contemporaries, who have both practically (morally), as well as theologically eliminated the role and historical consciousness of the cult of the martyrs and saints. As Peterson maintains, "rejection of the concept of the martyr" as ancillary to that of the original apostles and more generally, Christian discipleship, in fact "eliminates suffering for the Church-though suffering is necessarily linked with the preaching of the apostles-and thereby deprives the concept of the preaching of the gospel of its original meaning." ([3], p. 155). After all, apostolic witness and the prophetic munera of preaching the Gospel are not being received, as Peterson remarks, by a "neutrally disposed mankind that with its religious yearning might be ready to receive the apostles' proclamation of the kingdom of God with open arms. No; they are sent like sheep among wolves" ([3], p. 153).

By contrast, the presumption of a certain neutrality that recoils from such eschatological decisiveness becomes symptomatic, as Kierkegaard argues that the diffusiveness of this scenario is in fact more dangerous than all 'formal' heresies-which at least historically retained a clearer degree of partisan decisiveness-as he then diagnoses the times as largely "playing Christianity" that is entirely alien to moral asceticism, ecclesial suffering and instead, substitutes "power ... worldly goods, advantages, luxurious enjoyment of the most exquisite refinements ... to play it with such frightful earnestness that one cannot bring the game to a stop." ([27], p. 8). Such charges thus concern far more than simple material, luxurious excess. Instead, we hear Kierkegaard's radical prophetic critique concentrated later on in Berdyaev's own critique of modernity's "bourgeois consciousness", which in its explicitly idolatrous preference of the visible to that of the invisible, ultimately leads to a rejection of the Cross, pursuing instead its own calculative ends in direct "opposition to the tragic consciousness of life." ([29], p. 17). Herein, such a calculative rationality and outlook in no way discriminates between religious affiliation, or the lack thereof. Rather, "when he is a believer, belonging to some religious denomination, he is again the same artless realist ... .he does not connect this 'faith' of his with his outlook upon life and the world." ([29], p. 18). This utter nominalistic separation of life and the faith, the loss of sacramentality, the denial of the communion of saints and ultimately, that of the vocation of holiness itself are all indicative of this bourgeois religious temperament that Kierkegaard repeatedly inveighs against. For it is held captive solely by the 'earthly and temporal', as Kierkegaard cites, for example, the completely abstract, yet all-too-real calculative power of "number", and its "exercise over the imagination" ([27], pp. 30-31) in assessing the health and viability of Christian religious life today.

For his own part, Peterson explicitly takes up the complex legacy of Kierkegaard in his two related essays of 1947: "Kierkegaard und der Protestantismus" and "Existentialismus und Protestantische Theologie". In this latter essay, Peterson assesses such complexity as consisting largely in the divided reception history of Kierkegaard's religious and philosophical discourses, particularly within both German and French contexts. With Heidegger in particular, Peterson references a letter written to Karl Löwith, Heidegger's former student, wherein he confesses that only in 1921 did he "no longer follow the Kierkegaardian tendency" ([4], p. 52). Earlier on, however, Peterson recognizes the direct influence of several equivocal thinkers upon Heidegger, which continued to exert a foundational influence upon his later writings, all of which are rooted in the maior dissimilitudo of Christian thought, such as Kierkegaard, Pascal and the young Luther, the latter of whom ruthlessly attacked "the reason of scholastic philosophy ... as a whore" ([4], p. 52). And despite Heidegger admitting that he is no longer directly underneath Kierkegaard's influence, Peterson reads him within an optic of greater continuity and more generally, as representative of the overall secularization of foundational concepts 
within Protestant theology. For it was precisely under Heidegger's influence, Peterson maintains, "that we neglected the Christian and theological basis of Kierkegaard's thought", which, if anything, more properly belonged to the field of "Catholic asceticism", as opposed to transforming them into generalized concepts of "human existence ... deprived of every concrete meaning."([4], p. 54). Excavating such concretissimum became instead a generalized thinking of being's immanent historicity, while subsequently removing the martyr's "contemporaneity with Christ" and one's decision for God within a porous, transcendental horizon and instead, replacing it with a deformed decision for the 'Führer'.

Peterson's insistence upon Kierkegaard's refusal of such a secularizing hermeneutic is further examined in the essay, "Kierkegaard und der Protestantismus". If indeed the irreducible concretissimum of the martyr stands as a prophetic, irreconcilable counter to such "Vermittlungstheologie", then at its foundations, the martyr witnesses against the sola fide and its secularization that arises from the nominalistic split between faith and life within Danish Lutheran thought. At the source of Kierkegaard's prophetic ire, Peterson describes this theology of grace increasingly seen as solely gratuitous-“simply a 'favor Dei'" - that is far removed from the immanence of nature, history and life. Grace is thereby considered no longer integrally as either "infused" or "inherent" ([4], p. 58). The resulting paradox that Peterson describes is that one is both a sinner and righteous at the same time: "sinner in his real existence on this earth, righteous in his ideal existence before God in heaven." ([4], p. 58). Herein, the sola fide becomes an overly idealized, intellectual act that becomes utterly irreconcilable with the finitude of human agency that "loses all meaning" before the transcendent. Peterson situates many of Kierkegaard's well-known existentialist concepts as a immediate rejection of this nominalistic "Vermittlungstheologie". Peterson writes: "It seems to me that all those concepts-Existenz, the decision, the leap, the individual—formed by the Pietist in Kierkegaard, in contrast to Reformed orthodoxy, only have a real meaning for Catholics, who face the problem of his 'vocation'." ([4], p. 59). Likewise, the work of liturgy and charity become both functionalized and lose the specificity of their identity, suffering a bourgeois capture within the horizon of the visible and political. Thus, Peterson reminds us, Kierkegaard's "attack" is not a dogmatic one in the least, yet a moral one; that is, its ultimately an attack against a Christian nominalism for which in the world, the "saint did not exist" ([4], p. 60).

\section{Conclusions: The Martyrological Witness of the Poor as an Eschatological Symbol}

As we have seen in the preceding sections, the radical character of Peterson's apocalyptic eschatology invariably explores the necessary between of the Church in its refusal of bourgeois capture and principle vocation of holiness as a porous in-breaking of the transcendent beyond from within. Such a between and the central role of the martyr in witnessing the foundations of the Church ([3], p. 151) in her multitude presents a historical view of the suffering Church as necessarily beyond political confinement and ideological capture. As a pilgrim community in-between the "earthly Jerusalem, which is at once polis and temple" and its "ever drawing closer to the eschatological, heavenly temple and its own ... polis", Peterson's writings consistently bear witness to this ontic difference by framing the Church's distinctly public act, the liturgy, as the site of a transversal commericum: an angelic participation within the earthly cult as well as her "participation in the worship that the angels offer to God."([3], p. 107). Herein, Peterson's theo-political mysticism well anticipates Sacrosantum Concilium's own definitive pronouncements on the liturgy's porous exchange of praise and its eschatological significance that renders the fullness of Christian existence as fundamentally "foreign", with the Body and Bride, the Church, as a poor, wayfaring stranger. ${ }^{20}$

20 C.f. ([30], pp. 141-42): "In the earthly liturgy we take part in a foretaste of that heavenly liturgy which is celebrated in the holy city of Jerusalem toward which we journey as pilgrims, where Christ is sitting at the right hand of God, a minister of the holies and of the true tabernacle; we sing a hymn to the Lord's glory with all the warriors of the heavenly army; venerating the memory of the saints, we hope for some part and fellowship with them; we eagerly await the Savior, Our Lord Jesus Christ, until He, our life, shall appear and we too will appear with Him in glory." 
And yet, the very porosity that resists ideological capture simultaneously entails for Peterson both an absence of neutrality and an absence of retreat, as we have seen in view of the very decisiveness of the eschatological. Such decisiveness is matched by the totality of his theological vision, that at once invites us to patiently recover the cosmic vision of the metaphysical struggle between the angelic and the demonic as transecting the historical wherein the militia Christi is embedded in its own apocalyptic struggle that is neither apolitical or blithely escapist, but instead "inevitably stands either under the power of the Antichrist or the power of Christ." With Peterson, his theo-political approach supports neither the accomodationist views of a "lesser of two evils", nor can he be aligned with a static, "political Augustianism" that would readily subsume the secular into the ecclesial supernatural as the Church triumphant.

Instead, in view of his Kierkagaardian and Pietist strands, a more radical Catholic option consequently does indeed emerge from Peterson's writings, wherein the supernatural provides a critical contrast as both beyond, yet inseparable that expands and distinguishes the uniqueness of the Church's political vision and her commitments. It does so, par excellence, as we have seen, by way of the charism of the martyr, as foundational to the pilgrim Church, who both perceives and reveals, makes visible and thus public these dueling cities of Babylon and Jerusalem amid their dramatic cosmic and historical unfolding.

The eschatological coloring of this charism and its countless edifying accounts for those suffering to hold fast and patiently endure, frequently make either implicit or explicit reference to the Lukan narrative of the poor Lazarus, as an exemplar of such patient suffering, who eventually dies upon the threshold of the rich man's door. (Lk 16, 19-31). However, such comparisons rarely extend beyond the range of moral exhortation. In contrast, Peterson himself initiates the broader implications of such connections, and thereby in turn, the potential to constructively develop further and expand such an ecclesiology of martyrdom in terms of the martyrological witness of the poor as an eschatological symbol. In this regard, Peterson beautifully captures both the aporetic ambiguity and eschatological foreignness of the Lazarean figure in his short, theological parable, Der Reiche und der Arme ([4], pp. 41-43). For it is in this convergence, of the beyond from within, that theologically dramatizes the poor beyond sheer historical facticity and sociological confinement and instead infuses the poor thoroughly as a theological and ultimately eschatological mystery.

The frequent anonymity of the martyr both converges and is expanded in its ecclesial designation with the very suffering flesh of Christ in terms of the blessed poor. For Peterson, the mystery of the poor in whom Jesus blesses at the Sermon of the Mount is not confined to a thinking of identity. The "poor" do not merely align with a sociological, nor even a moral category, as the working class [Lumpenproletariat] constitutes a "segment that will always remain within human society and its class structure" ([23], p. 169). Nor are the poor designated, in contrast with the rich, within an optics of poros and penia and thus paradoxically without privation, as it is known by the tradition of "holy poverty" that St. John Chrysostom first developed ([31], pp. 39-56), and then later on by the Franciscans, who would describe such imitable poverty as "angelic" and thus befitting a monk. Instead, for Peterson, the poor in whom Christ blesses do not exist merely on the margins of society and thereby remain encapsulated and defined by this public precisely in terms of their exclusion; rather, the blessed poor Peterson identifies as those of whom "human society no longer even notices" as they exist not simply on the social margins, yet "on the very edge of the world itself." ([23], p. 169).

For indeed, as with the porosity and the tearing open that the martyr concretizes and reveals in his suffering flesh, Peterson indicates a similar breaking open with the poor, and one can only understand them and their witness by way of their profound relatedness with the angels. This angelic appearance does not so much function as an edifying injunction to embrace holy poverty; rather, the poor themselves publicly bear witness in their suffering flesh to the balm of the angels' kenotic, outpouring ministry. As Peterson narrates in describing his Lazarean character: "It was very odd that he never looked up and acknowledged the rich man" but instead, "the poor man always glances somewhere into the empty, but this nothing that he saw was for him very well also a mysterious 
something." ([4], p. 41). Peterson's narrative subtly innovates upon the well-known Lukan parable, as at one point he describes how the poor man, having been "abandoned by all men", was instead visited both by the dogs that "licked his sores" as well as those of the "angels, who carried him out of this world." ([4], p. 42). This detail becomes quite significant, as he thus explicitly draws out the Christological parallels and in turn, its expanded, martyrological significance, as Peterson summarizes that "there was only the possibility for the life of this son of man, that between the animal and the angel the poor man should lay and there should die before the door of the rich man." ([4], p. 42)

The appearance of such an angelic mediation and their kenotic, outpouring love and ecstatic service in ministering to the otherwise invisible poor should not be immediately cast outside as either pious ornamentalization nor as an unnecessary, additional "bureaucratic" layer of Peterson's theo-politics, as Agamben portrays him. ${ }^{21}$ Instead, Peterson signals that such angelic mediation is principally seen as endowing the "gathering together of the ekklêsia ... as a public entity" ([3], p. 135) within a clear eschatological view and thus beyond any and all extrinsic, legal grounding. Endowing the poor on the margins within such an ecclesial "public" dimension is thus crucial in understanding how he then comes to identify the blessed poor, not in an overly nominalistic, "spiritualized" sense, yet firmly as a mysterious, eschatological site of porosity:

So closely do they live to the edge of the world that Lazarus could, almost without realizing it, fall from the world ... he is carried from this world by the angels .... The poor man whom Jesus sees lies on the border between this world and another world. He becomes an eschatological symbol in whom Jesus recognizes himself. The poor man is recognized by the one who 'became poor for our sake' $(2$ Cor 8,9$) \ldots$ the concept of the poor man is inseparable from the Son of Man ([23], p. 169).

Here, the blessed poor, as an eschatological symbol, thus stands at the threshold, the very borderline of transcendence and immanence whereby such porosity breaks through. Like the martyrs' witness of the tearing of the heavens, the martyrological witness of the poor and their "lowly" prayer similarly "pierces the clouds; it does not rest till it reaches its goal; nor will it withdraw till the Most High responds." (Sir 35, 21). For Peterson, it is such an eschatological porosity that again raises the injunction of do unto the least of these, so too do you do to me beyond mere moral platitude. Rather, such a 'preferential option' can be seen as stemming precisely from this eschatological opening that facilitates a commercium and mystic identity between the poor and the Son of Man. For between Christ and those of whom, by their very lives, patiently endure in their witness to his very blessed name share an "eschatological fellowship of suffering and destiny" such that whoever "receives" him in hospitality or "gives even a cup of cold water to drink to one of these persecuted disciples" thereby in turn "receives the one who has sent him" ([3], p. 153).

In closing, by placing the theological significance of the poor's uniquely martyrological witness within a clear eschatological view, we can better appreciate the greater ontic thrust of Peterson's statement that the poor are a uniquely privileged "eschatological symbol in whom Jesus recognizes himself". Inversely, it is the rest of us, Peterson maintains, "who are neither rich nor poor" and for whom the poor remain largely invisible, suchunknowning captures the drama and the very decisiveness of the eschatological and the urgency of its appeal, which the poor and the martyrs alike continuously witness at its porous threshold.

Conflicts of Interest: The author declares no conflict of interest.

\section{References}

1. Barbara Nichtweiß. Vom Ende der Zeit: Geschichtstheologie und Eschatologie bei Erik Peterson. Münster: Lit Verlag, 2001.

21 C.f. ([32], ch. 6$)$. 
2. Erik Peterson. Frükirche, Judentum und Gnosis. Rome: Herder, 1959.

3. Erik Peterson. Theological Tractates. Stanford: University Press, 2011.

4. Erik Peterson. Marginalien zur Theologie: Und andere Schriften. Würzburg: Echter Verlag, 1995.

5. Erik Peterson. “Gilbert, Dom Hugh.” Translated by Dom Hugh Gilbert. Communio 1993, 20, 558-68.

6. Sergius Bulgakov. Jacob's Ladder: On Angels. Translated by Thomas Allan Smith. Grand Rapids: Eerdmans, 2010.

7. Barbara Nichtweiß. Erik Peterson: Neue Sicht auf Leben und Werk. Freiburg: Herder, 1992.

8. Rene Girard. “On War and Apocalypse.” First Things, August 2009.

9. Bernard McGinn. Apocalyptic Spirituality. Translated and Edited by B. McGinn. New York: Paulist Press, 1979.

10. Bernard McGinn. Visions of the End: Apocalyptic Traditions in the Middle Ages. New York: Columbia University Press, 1979.

11. Ernst Käsemann. New Testament Questions of Today. Translated by W. J. Montague. Philadelphia: Fortress Press, 1969.

12. Michael Hollerich. "Existence in Christ: Erik Peterson and the Postwar Crisis of Humanism." Logos 16 (2013): 147-63. [CrossRef]

13. Christopher Rowland. Radical Christianity: A Reading of Recovery. Cambridge: Polity, 1988.

14. Christopher Rowland. "Apocalyptism and Radicalism." In The Oxford Handbook of Apocalyptic Literature. Edited by John J. Collins. Oxford: University Press, 2014.

15. Vladimir Solovyov. Sophia, God \& a Short Tale about the Antichrist. Translated by Boris Jakim. Kettering: Angelico Press, 2014.

16. St. Maria Faustina Kowalska. Diary: Divine Mercy in my Soul. Stockbridge: Marian Press, 2004.

17. Hille Haker, Andrés Torres Queiruga, and Marie-Theres Wacker. "The Return of Apocalypticism." Concilium 3 (2014): 7-15.

18. John Allen, Jr. The Global War on Christians: Dispatches from the Front Lines of Anti-Christian Persecution. New York: Image, 2013.

19. Johannes-Baptist Metz, and Edward Schillebeeckx. "Martyrdom Today." Concilium 163 (1983): vi-vii.

20. Franz Jägerstätter. Letters and Writings from Prison. Edited by Erna Putz. Translated by Robert A. Krieg. Maryknoll: Orbis, 2009.

21. Leonardo Boff. "Martyrdom: An Attempt at Systematic Reflection." Translated by Paul Burns. Concilium 163 (1983): 11-17.

22. William Stringfellow. An Ethic for Christians and Other Aliens in a Strange Land. Waco: Word Books, 1973.

23. Erik Peterson. "What is Man." Translated by Michael Hollerich. Logos 16 (2013): 164-73. [CrossRef]

24. Clement of Alexandria. The Rich Man's Salvation. Translated by G. W. Butterworth. Cambridge: Harvard University Press, 2003.

25. Francis. "Address to the Jesuits on the occasion of its Bicentennial Reestablishment September 27, 2014." Available online: http://w2.vatican.va/content/francesco/en/speeches/2014/september/documents/ papa-francesco_20140927_vespri-bicentenario-ricostituzione-gesuiti.html (accessed on 12 December 2016).

26. Joshua Furnal. Catholic Theology after Kierkegaard. Oxford: University Press, 2016.

27. Soren Kierkegaard. Attack upon Christendom-1854-1855. Translated by Walter Lowrie. Princeton: University Press, 1968.

28. Christopher Barnett. Kierkegaard, Pietism and Holiness. Burlington: Ashgate, 2011.

29. Nicholas Berdyaev. The Bourgeois Mind and Other Essays. Translated by Countess Benningsen and Donald Attwater. Freeport: Books for Libraries Press, 1964.

30. "Sacrosantum Concilium." In The Documents of Vatican II. Edited by Walter M. Abbott, S.J. New York: Guild Press, 1966.

31. St. John Chrysostom. On Wealth and Poverty. Translated by Catharine P. Roth. Crestwood: St. Vladimir's Seminary Press, 1981.

32. Giorgio Agamben. The Kingdom and the Glory: For a Theological Genealogy of Economy and Government. Translated by Lorenzo Chiesa and Matteo Mandarini. Stanford: University Press, 2011.

(C) 2017 by the author. Licensee MDPI, Basel, Switzerland. This article is an open access article distributed under the terms and conditions of the Creative Commons Attribution (CC BY) license (http:/ / creativecommons.org/licenses/by/4.0/). 